\title{
Alcohol hepatotoxicity: Kupffer cells surface to the top
}

\author{
P. Godoy $\cdot$ R. Reif $\cdot$ H. M. Bolt
}

Published online: 15 August 2012

(C) Springer-Verlag 2012

In this issue of the Archives of Toxicology, Arthur I. Cederbaum from New York Mount Sinai School of Medicine gives a review on cytokine-mediated hepatotoxicity including a state-of-the-art discussion of the involved signalling pathways (An et al. 2012). A key mechanism of alcoholic liver disease is that ethanol consumption increases levels of gut-derived endotoxins to the portal circulation. As a consequence, Kupffer cells are activated through Toll-like receptors, particularly Toll-like receptor 4 (TLR-4). A well-known consequence of TLR-4-mediated activation of Kupffer cells is secretion of tumour necrosis factor alpha $(\mathrm{TNF}-\alpha)$, which mediates inflammation and apoptosis. TNF- $\alpha$ signals through two receptors, TNF- $\alpha-\mathrm{R} 1$ and TNF- $\alpha-\mathrm{R} 2$, which are expressed at higher levels on the hepatocyte membranes compared to all other (non-parenchymal) liver cell types. Therefore, TNF- $\alpha$ is a prototypical cytokine of the Kupffer cell-hepatocyte axis. Cederbaum discusses a number of further mechanisms relevant to alcoholic liver disease, including IL-8 and IL-18, the protective role of adiponectin, AMP-activated protein kinase and transcription factors regulating lipid synthesis, such as SREBPS and sirtuin 1.

Hepatotoxicity remains a major reason for drug withdrawal from clinical use (Hewitt et al. 2007; Knobeloch et al. 2012). Therefore, a lot of energy is currently invested into development and improvement of hepatocyte in vitro systems to predict hepatotoxicity (De Kock et al. 2011; Wobus and Löser 2011; Heise et al. 2012; Zellmer et al. 2010; Godoy et al. 2009, 2010a, b; Schumann et al. 2009).

P. Godoy $(\bowtie) \cdot$ R. Reif $\cdot$ H. M. Bolt Leibniz Research Centre for Working Environment and Human Factors (IfADo), Leibniz Institut für Arbeitsforschung an der TU Dortmund, Ardeystrasse 67, 44139 Dortmund, Germany e-mail: godoy@ifado.de
However, one of the critical aspects highlighted in the article of Arthur Cederbaum is that hepatocytes may not be the primary 'sensor' of hepatotoxicity, but rather react to cytokines released from Kupffer cells. Similar constellations have been reported for other non-parenchymal liver cells, such as sinusoidal endothelial cells and stellate cells (Hoehme et al. 2010; Ding et al. 2010). One of the merits of the current review (An et al. 2012) is that it highlights the role of cell-cell communication between non-parenchymal cells and hepatocytes. The article is a must-read for anyone interested in mechanisms of hepatotoxicity.

\section{References}

An L, Wang X, Cederbaum AI (2012) Cytokines in alcoholic liver disease. Arch Toxicol (this issue). doi:10.1007/s00204-0120814-6

De Kock J, Ceelen L, De Spiegelaere W, Casteleyn C, Claes P, Vanhaecke T, Rogiers V (2011) Simple and quick method for whole-liver decellularization: a novel in vitro three-dimensional bioengineering tool? Arch Toxicol 85(6):607-612

Ding BS, Nolan DJ, Butler JM, James D, Babazadeh AO, Rosenwaks Z, Mittal V, Kobayashi H, Shido K, Lyden D, Sato TN, Rabbany SY, Rafii S (2010) Inductive angiocrine signals from sinusoidal endothelium are required for liver regeneration. Nature 468(7321):310-315

Godoy P, Hengstler JG, Ilkavets I, Meyer C, Bachmann A, Müller A, Tuschl G, Mueller SO, Dooley S (2009) Extracellular matrix modulates sensitivity of hepatocytes to fibroblastoid dedifferentiation and transforming growth factor beta-induced apoptosis. Hepatology 49(6):2031-2043

Godoy P, Schug M, Bauer A, Hengstler JG (2010a) Reversible manipulation of apoptosis sensitivity in cultured hepatocytes by matrix-mediated manipulation of signaling activities. Methods Mol Biol 640:139-155

Godoy P, Lakkapamu S, Schug M, Bauer A, Stewart JD, Bedawi E, Hammad S, Amin J, Marchan R, Schormann W, Maccoux L, von Recklinghausen I, Reif R, Hengstler JG (2010b) Dexamethasone- 
dependent versus -independent markers of epithelial to mesenchymal transition in primary hepatocytes. Biol Chem 391(1):73-83

Heise T, Schug M, Storm D, Ellinger-Ziegelbauer H, Ahr HJ, Hellwig B, Rahnenfuhrer J, Ghallab A, Guenther G, Sisnaiske J, Reif R, Godoy P, Mielke H, Gundert-Remy U, Lampen A, Oberemm A, Hengstler JG (2012) In vitro-in vivo correlation of gene expression alterations induced by liver carcinogens. Curr Med Chem 19(11):1721-1730

Hewitt NJ, Lechón MJ, Houston JB, Hallifax D, Brown HS, Maurel P, Kenna JG, Gustavsson L, Lohmann C, Skonberg C, Guillouzo A, Tuschl G, Li AP, LeCluyse E, Groothuis GM, Hengstler JG (2007) Primary hepatocytes: current understanding of the regulation of metabolic enzymes and transporter proteins, and pharmaceutical practice for the use of hepatocytes in metabolism, enzyme induction, transporter, clearance, and hepatotoxicity studies. Drug Metab Rev 39(1):159-234

Hoehme S, Brulport M, Bauer A, Bedawy E, Schormann W, Hermes M, Puppe V, Gebhardt R, Zellmer S, Schwarz M, Bockamp E, Timmel T, Hengstler JG, Drasdo D (2010) Prediction and validation of cell alignment along microvessels as order principle to restore tissue architecture in liver regeneration. Proc Natl Acad Sci U S A 107(23):10371-10376

Knobeloch D, Ehnert S, Schyschka L, Büchler P, Schoenberg M, Kleeff J, Thasler WE, Nussler NC, Godoy P, Hengstler J, Nussler AK (2012) Human hepatocytes: isolation, culture, and quality procedures. Methods Mol Biol 806:99-120

Schumann A, Bauer A, Hermes M, Gilbert M, Hengstler JG, Wilhelm C (2009) A rapid and easy to handle thermoluminescence based technique for evaluation of carbon tetrachloride-induced oxidative stress on rat hepatocytes. Arch Toxicol 83(7):709-720

Wobus AM, Löser P (2011) Present state and future perspectives of using pluripotent stem cells in toxicology research. Arch Toxicol 85(2):79-117

Zellmer S, Schmidt-Heck W, Godoy P, Weng H, Meyer C, Lehmann T, Sparna T, Schormann W, Hammad S, Kreutz C, Timmer J, von Weizsäcker F, Thürmann PA, Merfort I, Guthke R, Dooley S, Hengstler JG, Gebhardt R (2010) Transcription factors ETF, E2F, and SP-1 are involved in cytokine-independent proliferation of murine hepatocytes. Hepatology 52(6):2127-2136 